\title{
4 The mining industry, conflict, and the Church's commitment in the Democratic Republic of the Congo
}

\author{
Rigobert Minani, $S J^{1}$
}

In 2019, the links between the extractive industry and the escalation of conflicts in the Democratic Republic of the Congo (DRC) were documented in a report to the UN Security Council (30-38). For over two decades, experts on the Great Lakes region, including diplomats, researchers, NGOs, and journalists, have identified the looting of mineral resources in the DRC as a structural cause of conflict (UN Security Council 2001; Jacquemont 2009; Cuvelier and Raeymaekers 2002). Since the outbreak of war in 1996, the plundering of natural and mineral resources in the DRC has fueled, escalated, and prolonged violence. The Church in the DRC has made a significant commitment to promoting good governance of these resources in order to help halt conflict and consolidate peace and stability.

\section{Origin of the problem}

The current problem did not start with the war of 1996. It goes back to the time of King Leopold II and the Berlin Division of colonial Africa in the late nineteenth century, as well as the turmoil of the postcolonial era. After independence in 1960, the country experienced significant sociopolitical difficulties. By 1975, the economy was failing, due to the fall in the price of copper, the oil crisis, the closure of the export route through the port of Lobito in Angola, and the hazardous economic policies of the Mobutu regime (Minani 2007, 502). These economic issues coincided with the Shaba War (March 1977-May 1978) and the massive departure of expatriate staff (Trinquier, Duchemin, and LeBailly 1963; Brassart 2018). The annual revenue of Gécamines, the state mining company, dropped from US $\$ 10$ billion in 1974 to US\$3.8 billion in 1990 (National Assembly of the Democratic Republic of the Congo 2006, 3).

On the eve of the DRC's series of wars starting in 1996, the country had been mired in a failed democratization process for at least seven years, its economy was at its lowest, and international cooperation had been suspended since May 1992. In short, the state was politically unstable and economically asphyxiated. These combined factors favored the outbreak of war, making possible the invasion of the country, the collapse of its security

DOI: $10.4324 / 9781003094272-4$ 
apparatus, and a scramble to loot the DRC's mineral resources that involved more than nine African countries.

\section{Privatization of the mining sector and escalation of the conflict}

A few months before the war started, the World Bank and the International Monetary Fund came to the rescue of the Congolese economy. The country was asked to align with the World Bank's Structural Adjustment Policy. In 1995, under the aegis of these institutions, the country launched a major privatization of public enterprises, particularly the mining sector. According to a 2006 report from the DRC National Assembly, "The objective of this operation was twofold: pay down the country's debt by having foreign companies pay fees directly to international financial institutions, and replenish the state's coffers which had been drained by lax budget management" (5).

This operation allowed the wolf into the sheepfold. This was not the best time for this economic change. Internally, the Mobutu regime was at its end. Since 1992, opposition parties, churches, and civil society groups had asked Mobutu to leave power and the winds of democratization were shaking the country. The Mobutu regime did not, at this time, have sufficient credibility or legitimacy to execute a massive economic overhaul. With the end of the Cold War, international markets favored the mobility of capital on a global scale. The international financial institutions' economic reform measures were therefore very risky and poorly timed (Minani 2007, 503). And the privatization of mining companies in the DRC was fatal for its economy. The action amounted to a selloff of national wealth and it empowered illegal armed groups and other military actors. The period also coincided with the explosion of violence in the Great Lakes countries, with war in Burundi and genocide in Rwanda. The DRC experienced not only internal violence, but also spillover fighting from other countries near its borders. Mining companies raced to obtain mining titles sold at low prices because of war. And they also negotiated with the groups that had military control in the areas to be developed, giving the armed groups resources and power. From that moment on, control of mines became part of the war strategy.

The outbreak of conflict and the policies of the international financial institutions led the faltering government in Kinshasa to accelerate the slicing of its mining portfolio and the selloff of the nation's mining heritage. The government needed, on the one hand, to have funds to face the war, and, on the other hand, to build new alliances. Therefore, while the east of the country was occupied by rebels and foreign troops, the government accelerated the signing of agreements that sold off mining resources, sacrificing long-term sources of revenue and economic stability for needed cash-in-hand (Minani 2007, 505). 


\section{Mineral resources as fuel for conflicts in the DRC}

Both the government in Kinshasa and the rebel group of Laurent Désiré Kabila engaged in haggling over mines with various actors, including criminals. Soon after the war began the government could no longer be a reliable partner for companies because it quickly lost control of a large part of its territory. The mining companies began to deal with the rebel leader Kabila in Goma. The rebels took advantage of these solicitations to strengthen themselves financially and militarily, and some of the contracts they signed with companies were for sites that had already been negotiated by Kinshasa, effectively redistributing revenue from the government to the rebels. This allowed Kabila to pay short-term bills, pay day-to-day expenses of his army, and fund his politico-administrative apparatus (Baracyetse $1999,8)$. Helped by this money from mining, the support of neighboring countries, and international complicity, Kabila took power on May 17, 1997. Hardly a year later, on August 2, 1998, a new war broke out. Exacerbated by mining, this war became worse than the first one.

During the second war, rebel political alliances were reconfigured. The country was divided into five regions, each controlled by one faction. ${ }^{2}$ Each group retreated to the mines in the areas it controlled to finance the group's war efforts. The rebel movements occupied mainly the eastern and northern DRC, while the government controlled the western and southern areas. That gave the government control of copper and cobalt mines in Katanga. For the rebel groups, the exploitation of gold in Ituri province, diamonds in Kisangani region, and gold and coltan in North and South Kivu became important.

The period also corresponded to a major spike in international demand for coltan, an important component in the personal electronics boom in the West. Coltan was exploited by, among others, armed groups, and marketed by neighboring countries, mainly Rwanda. It passed through refining plants in Europe, America, and Asia, and reached high-tech industries through a complex circuit (Cuvelier and Raeymaekers 2002, 9).

This rush for mining tipped the DRC into a criminalized economy. As I have written elsewhere, "The political weight of each rebel faction was proportional to the natural resources it controlled, according to its own rules of the game and its relationship with its allies" (Minani 2007, 507). Additionally, foreign countries involved in the conflicts, namely Rwanda and Uganda, were allowed to exploit the minerals in the DRC in exchange for support for rebel factions.

On April 1, 2003, the DRC concluded a peace agreement and put in place a transition government. Foreign troops were asked to withdraw, but neighboring countries, especially Rwanda and Uganda, strengthened their links with new armed groups in Kivu, Ituri, and elsewhere in eastern DRC in order to maintain control over the territory and access to natural resources. According to UN reports this was part of a long-planned strategy 
(UN Security Council 2003, sec. 43-47). It escalated conflicts that have remained impervious to multiple peace initiatives. The death toll and the humanitarian crisis caused by this war, financed by the minerals in the DRC, mobilized a large number of international NGOs. Many Catholic actors in the DRC and around the world participated in several campaigns, with mixed results. None has succeeded in putting a final end to this scourge, but Congolese Catholics and their international partners have formed a powerful coalition to face these seemingly interminable problems.

\section{Good governance of the mining sector and the Church's commitment}

The Catholic Church in the DRC has always been at the forefront of social and political engagement, and the impact of extractive industries on conflicts has been a major concern since the early 2000s. As the Congolese bishops noted in 2007, their action on mining arises from the fact that extractive industries are a source of great wealth for some while being a source of great harm for many:

Instead of contributing to the development of our country and benefiting our people, minerals, oil, and the forest have become causes of our misfortune. How do we take the fact that our fellow citizens, without consideration or compensation, are stripped of their land...? Is it permissible for Congolese workers to be treated without regard for their rights and human dignity? $(\$ 10)$

The Jesuit Center of Study and Social Action (CEPAS) $)^{3}$ took the lead on this issue. In 2006, it initiated a forum of civil society organizations to reflect on good governance of natural resources. This forum led to a campaign, initiated in March 2007 by DRC civil society groups and a coalition of international NGOs, calling for a revision of mining contracts extremely unfavorable to the DRC. A press release from the coalition stated: "The NGOs are calling on the Congolese Government and its international partners to renegotiate, revoke, or cancel the contracts inherited from the war and the transition in order to ensure that the Congolese people derive a fair share from the benefits of the exploitation of the country's mineral wealth" (A Fair Share for Congo/Une part équitable pour le Congo 2007). The campaign requested assurances of transparency, from the government and the World Bank, for past mining contracts. Specifically, it asked that the Congolese government establish a working group of independent international and Congolese experts to: review and revise all mining contracts signed during the war; establish an independent mechanism for monitoring the execution of contracts; and enshrine conditions for transparent and equitable management of mineral resources in the future (Minani 2007, 515). 
To anticipate the results of such an exercise, CEPAS engaged mining evaluation experts, including former managers of Gécamines, to study the clauses of twelve contracts signed between the government and mining companies ("Republique Democratique du Congo revisitation des contrats miniers" 2007). They came to the conclusion that the review of the mining contracts was necessary so as to correct violations of the Mining Code, revive the economy, and improve the socioeconomic condition of Congolese citizens. This initiative laid a foundation for the government to revisit sixty-one contracts signed during the war. The Catholic bishops' conference of the DRC (CENCO) and CEPAS were invited to observe the process. At the end, the Ministry of Mines of the Democratic Republic of the Congo (2009) entrusted publication of the official government report to CEPAS. Unfortunately, when the time came to actually renegotiate contracts, it was done exclusively between the government and mining companies with no outside experts or observers. And because of confidentiality language included in the contracts, no details were made public.

Around this time, ecclesial leaders began focusing more on issues of mining. In 2007, the Assembly of Bishops of the Ecclesiastical Province of Lubumbashi, a group of pastors in Katanga, the main mining province of the DRC, wrote a pastoral letter that applied elements of the church's social doctrine to governance of extractive industries. This letter strongly condemned the fact that "the more investors ... invade Katanga, the more poverty, unemployment, and social problems increase" (\$31). It affirmed the fact that minerals were neither benefiting the population nor the state. Workers were getting poorer, local economies were not strengthened, and artisanal miners were being arrested, tortured, and even killed. The more companies' profits grew, the more local communities suffered. It is against this background that the bishops of Katanga demanded that the Congolese state put the mining sector in order: "Congo is neither for sale nor on sale. ... The riches of our province must benefit our people ... [A]nd working conditions [must be] consistent with human dignity” $(\$ 34)$. The bishops also encouraged the government to diversify its economic development strategies by investing in agriculture, tourism, timber, and fishing in anticipation of the depletion of mineral resources.

Inspired by the work of CEPAS and the witness of the Katanga bishops, CENCO, in July 2007, decided to create an ad hoc episcopal commission in charge of natural resource governance:

CENCO is committed, through its structures, to follow with particular attention the process of 'revision' of mining and forests contracts so that it can be done in the greatest transparency for the benefit of the Congolese people. It believes that the proper management of national resources will be a determining factor for the rebirth of the DRC. CENCO will create an ad hoc Episcopal Commission within its own 
body responsible for monitoring the issue of the exploitation of natural resources and demanding respect for human rights by companies working in this sector. $(\mathbb{1 0})$

In 2013, the ad hoc group became a full commission of CENCO, the Episcopal Commission for Natural Resources (CERN). Its mission is to study all issues related to the exploitation of natural resources and propose to the church means of intervention to promote good governance of these resources and prevent conflicts.

CERN has played several roles. It acts at the level of decision-makers through advocacy to influence laws and policies related to the exploitation and management of natural resources in the DRC. It informs, trains, and raises awareness for citizens' control and management of natural resources, and advocates for the adoption of responsible economic, social, cultural, and environmental lifestyles. It works with local, national, regional, and international civil society organizations with similar objectives, as well as with other politico-administrative and economic bodies. CERN has established natural resource observatories in dioceses that document cases of human rights violations against communities and promote public awareness.

CENCO's deep engagement on the 2010 Dodd-Frank Wall Street Reform and Protection Act is a key example of the systematic, transnational approach the church has taken on mining. This US legislation included landmark provisions to ensure greater transparency in the supply chain of minerals. CENCO was centrally involved in the campaign to get DoddFrank passed. During the time when the legislation was taking shape, the president of CENCO was Bishop Nicolas Djomo Lola. His leadership and lobbying of Western governments were very influential in the law's formation (Carney 2014, 109). He testified before Congress in 2010 to support the law's passage, and again in 2012 during a hearing about the law's effects. At that 2012 hearing, he argued that the law should not be softened to make the regulatory process easier on businesses:

We urge the U.S. business community to account for the gruesome social costs of the illicit mining as they calculate their costs for compliance with Section 1502. These calculations are not just cost estimates on a spreadsheet. There is a social balance sheet that places value on the lives that can be saved. We have full confidence in the goodwill of the Congress, the SEC [the US Securities and Exchange Commission], and the business sector to resist watering down SEC regulations through half measures that may save money, but cost lives. (US Congress 2012, 21)

Since Dodd-Frank's passage, and since the passage of similar regulations in Australia, Canada, and the EU, CENCO and CERN have continued to 
support transparency efforts. In 2017, when many believed that the United States might repeal the conflict mineral provisions in Dodd-Frank, CENCO's Henry Muhiya argued that the repeal would lead to new risks of conflict over minerals and would undermine local development programs begun as part of the DRC's efforts to comply with the law (Bagnetto 2017). In 2019, with financial support from CORDAID, CERN published a study on the impact of artisanal mining on local development. They then organized a workshop in 2020 with government and civil society representatives to examine how artisanal mining can be integrated into transparency regulation (ITIE-RDC Communication Unit n.d.). These independent, smallscale miners could be blocked from meaningful market participation if they are not enabled to navigate the regulatory frameworks made necessary by transparency laws. The recommendations emerging from the workshop included calling on the government to make sure technical assistance for transparency regulation is made available to these miners and that transparency frameworks are created that are specific to the artisanal sector. These kinds of initiatives led the Extractives Industry Transparency Initiative (EITI) $(2019,25)$ to highlight CERN as one of the leading Congolese organizations engaged in advancing EITI standards.

\section{Conclusion}

The experience of the DRC shows that a better understanding of mining's influence on conflict could help improve interventions to prevent and reduce conflict, and build lasting peace. The social doctrine of the church can help reveal the limits of the promises of the extractive industry (Minani 2017). Pope Francis $(2015, \mathbb{\$} 93)$ reminds us that “A type of development which did not respect and promote human rights-personal and social, economic and political, including the rights of nations and of peoples-would not be really worthy of man." He criticizes industries, such as mining, with short-sighted development models. Such development is at odds with the teaching of the church in the sense that it proposes a massive exploitation of resources without worrying about future generations. It aims at a rapid enrichment of investors and leaves local communities in poverty.

The extractive industry also has serious environmental consequences, including deforestation, land degradation, and contamination of air and water. The actors in the industry, including the government, armed groups, and multinational companies, also promote the expulsion of communities from their lands and contribute to massive violations of human rights. This situation in the DRC has contributed to violent conflicts, including an explosion of militias in Kivu today. The church's action for conflict transformation and peacebuilding in the mining sector is complex. It is, as Pope Francis $(2020, \mathbb{\$} 14)$ says, a fight against an economic instrument of death. The church needs to help the mining industry to better understand and care 


\section{Rigobert Minani, SJ}

about the impact of its operations and the security and well-being of populations. The Catholic Church in the DRC has been actively engaged in many ways to try to help bring about this change.

\section{Notes}

1 Translated from French by Florence Silole.

2 West and Southeast of DRC: the Kinshasa government; North Kivu, South Kivu, Maniema and Sankuru regions: Rassemblement congolais pour la démocratie nationale-Goma; Equator region: Mouvement de liberation du Congo; Ituri region: Rassemblement congolais pour la démocratie nationale-Kisangani; Beni and Lubero region: Rassemblement congolais pour la démocratie nationale-K/ML.

3 See https://www.cepas.online.

\section{References}

Assembly of Bishops of the Ecclesiastical Province of Lubumbashi. 2007. "Que notre espoir ne soit jamais décu (Cf Ps, 70, 1)." March 3, 2007. https:// www.congoforum.be/fr/2007/03/11-03-07-que-notre-espoir-ne-soit-jamais-dumessage-de-lassemble-des-evques-du-katanga.

Bagnetto, Laura Angela. 2017. "Future of DR Congo Mining Could Be on Rocky Ground if US Dodd Frank 1502 Rolled Back.” RFI, March 7, 2017. https:// www.rfi.fr/en/africa/20170307-future-drc-mining-could-be-rocky-ground-if-usdodd-frank-1502-rolled-back.

Baracyetse, Pierre. 1999. "L'enjeu géopolitique des Sociétés minières internationales en République démocratique du Congo (ex-Zaïre)." Press release for SOS Rwanda-Burundi Buzet (Belgium).

Brassart, Pierre. 2018. Kolwezi 1978: Au Cour des opérations françaises et Belge au Zaïre. Paris: Mardaga.

Carney, J.J. 2014. “'The Bishop is Governor Here': Bishop Nicolas Djomo and Catholic Leadership in the Democratic Republic of the Congo." In Leadership in Postcolonial Africa: Trends Transformed by Independence, edited by Baba G. Jallow, 97-122. New York: Palgrave Macmillan.

CEPAS. 2006. Bonne gouvernance et ressources naturelles et minières en République démocratique du Congo. Kinshasa: Éditions CEPAS.

Cuvelier, Jeroen, and Tim Raeymaekers. 2002. "Supporting the War Economy in the DRC: European Companies and the Coltan Trade.” IPIS Report. January 16, 2002. https://ipisresearch.be/publication/supporting-the-war-economy-in-the-drceuropean-companies-and-the-coltan-trade.

EITI International Secretariat. 2019. Validation of the Democratic Republic of Congo: Report on Initial Data Collection and Stakeholder Consultation. April 15, 2019. https://eiti.org/files/documents/drc_2018_validation_initial_assessment_ final_april_2019.pdf.

A Fair Share for Congo/Une part équitable pour le Congo. 2007. "International Appeal for a Revision of the DRC's Mining Contracts." Press Release. March 13, 2007. http://www.raid-uk.org/sites/default/files/pr-contracts-campaign.pdf.

Francis. 2015. Laudato Si'. https:/www.vatican.va/content/francesco/en/encyclicals/ documents/papa-francesco_20150524_enciclica-laudato-si.html. 
Francis. 2020. Querida Amazonia. http://www.vatican.va/content/francesco/en/ apost_exhortations/documents/papa-francesco_esortazione-ap_20200202_ querida-amazonia.html.

ITIE-RDC Communication Unit. n.d. "Cern-Cenco: plaidoyer pour l'intégration du secteur minier artisanal à l'ITIE et au financement du ST par le Gouvernement." ITIE-RDC. Accessed April 22, 2021. https://www.itierdc.net/2020/09/24/cerncenco-plaidoyer-pour-lintegration-du-secteur-minier-artisanal-a-litie-et-au-financement-du-st-par-le-gouvernement.

Jacquemont, Pierre. 2009. "La sortie de crise dans l'Est du Congo et les perspectives de la Coopération Régionale.” Mondes en Developpement 37, no. 147: 93-108.

Minani, Rigobert. 2007. "La problématique des ressources minières en RDC: Etat de lieu et perspectives." Congo-Afrique 417: 501-518.

Minani, Rigobert, ed. 2017. Unmet Promises of Extractive Industries in Africa. Nairobi: Paulines Africa.

Ministry of Mines of the Democratic Republic of the Congo. 2009. Commission de Revisitation des contrats miniers: Rapport des travaux. 2 vols. Kinshasa: Éditions CEPAS.

National Assembly of the Democratic Republic of the Congo. 2006. Commission spéciale chargée de l'examen de la validité des conventions à caractère économique et financier conclues pendant les guerres, 1996-1997 et de 1998. Work report, part 1.

National Episcopal Conference of the Congo. 2007. "'A vin nouveau, outres neuves' (mc 2, 22): Ne pas décevoir les attentes de la nation.” http://www.virunganews.com/ a-vin-nouveau-outres-neuves-mc-2-22-ne-pas-decevoir-les-attentes-de-la-nation.

"Republique Democratique du Congo revisitation des contrats miniers: rapport du groupe d'experts du forum de la société civile sur 12 contrats miniers." 2007. http://pratclif.com/mines/kamoto/revisionContrats_miniers_Rapport_definitif.pdf.

Trinquier, Colonel [Roger], Jacques Duchemin, and Jacques LeBailly. 1963. Notre guerre au Katanga. Paris: La Pensée Moderne.

UN Security Council. 2001. Democratic Republic of Congo Asserts Right to Seek Help in Defense of Natural Wealth Against Outside Forces. Press Release SC/ 7241. December 14, 2001. https://www.un.org/press/en/2001/sc7241.doc.htm.

UN Security Council. 2003. Letter dated 15 October 2003 from the Chairman of the Panel of Experts on the Illegal Exploitation of Natural Resources and Other Forms of Wealth of the Democratic Republic of the Congo Addressed to the SecretaryGeneral. S/2003/1027. October, 23, 2003. https://undocs.org/S/2003/1027.

UN Security Council. 2019. Final Report from the Group of Experts on the Democratic Republic of the Congo. S/2019/469. June 7, 2019. https://undocs.org/ S/2019/469.

US Congress. 2012. House. Subcommittee on International Monetary Policy and Trade of the Committee on Financial Services. The Costs and Consequences of Dodd-Frank Section 1052: Impacts on America and the Congo.112th Congress, May 10, 2012. Statement of The Most Reverend Nicolas Djomo Lola, Bishop of Tshumbe, Democratic Republic of the Congo and President of the National Episcopal Conference of the Congo. https:/www.govinfo.gov/content/pkg/ CHRG-112hhrg75730/html/CHRG-112hhrg75730.htm. 